\title{
The Use of RNA Probes for the Analysis of Gene Expression
}

\author{
Dominique Belin
}

\begin{abstract}
The monomeric bacteriophage RNA polymerases allow the synthesis of virtually any RNA molecule in
unlimited quantity. In this protocol, we describe the preparation of plasmid and PCR-derived templates.
A basic transcription protocol is provided with several optional modifications. The use of RNA probes in
Northern blot hybridization and in RNase protection assays is described. The relative advantages and pitfalls
of these two methods to quantitatively detect mRNA targets are discussed.
Index Entries: RNA; riboprobe; phage; RNA polymerase; transcription; hybridization.
\end{abstract}
\section{Introduction}

The isolation and characterization of RNA polymerases from the Salmonella phage SP6 and the Escherichia coli phages T7 and T3 have revolutionized all aspects of the study of RNA metabolism (1-6). Indeed, it is now possible to generate unlimited quantities of virtually any RNA molecule in a chemically pure form. This technology is based on a number of properties of the viral transcription units. First, and in contrast to their cellular counterparts, the enzymes are single-chain proteins that were easily purified from phage-infected cells and are now produced by recombinant DNA technology. Second, they very specifically recognize their own promoters ( 7 and references therein), which are contiguous 17- to 20-bp-long sequences rarely encountered in bacterial, plasmid, or eukaryotic sequences. Third, the enzymes are highly processive, allowing the efficient synthesis of very long transcripts from DNA templates. In this article, I discuss the preparation of the DNA templates, the transcription from the templates of labeled synthetic RNA molecules, commonly called riboprobes, and their use in Northern and RNase protection assays.

\section{Materials}

These protocols require the use of standard molecular biology materials and methods for carrying out subcloning, polymerase chain reaction (PCR), and gel electrophoresis, in addition to those listed herein. More rigorous precautions are required for working with RNA than are commonly used for most DNA studies, because it is important to avoid RNase contamination. The two major sources of unwanted RNases are the skin of investigators and microbial contamination of solutions. Most RNases do not require divalent cations and are not irreversibly denatured by autoclaving. Gloves should be worn and frequently changed. Sterile plasticware should be used, although some mechanically manufactured tubes and pipet tips have been used successfully without sterilization. Glassware should be incubated at $180^{\circ} \mathrm{C}$ in a dried baking oven for several hours. In addition, divalent cations (such as $\mathrm{Mg}^{2+}$ or $\mathrm{Ca}^{2+}$ ) accelerate base-mediated RNA hydrolysis. RNA can be stored in sterile water, but is most stable when stored in $1 \mathrm{mM} \mathrm{KOAc}, \mathrm{pH} 5.0$, with $0.1 \mathrm{~m} M$ EDTA.

Address to which all corespondence and reprint requests should be addressed. Department of Pathology, University of Geneva Medical School, CMU, 1 rue Michel-Servet, CH-1211 Geneva, Switzerland, e-mail: dominique.belin@medecine.unigo.ch 


\subsection{Preparation of Riboprobes}

1. Water: Although a number of protocols recommend treatment of the water used for all the solutions with diethylpyrocarbonate, I find this to be unnecessary. Double-distilled water is used for the preparation of stock solutions that can be autoclaved $\left(121^{\circ} \mathrm{C}, 15-30 \mathrm{~min}\right)$, and sterilized water is used otherwise.

2. TE: $10 \mathrm{~m} M$ Tris-HCl, $\mathrm{pH} 8.1$, and $1 \mathrm{~m} M$ ethylene-diamine tetraacetic acid (EDTA).

3. $10 \mathrm{X}$ TB: $0.4 M$ Tris- $\mathrm{HCl}, \mathrm{pH} 7.4,0.2 \mathrm{M} \mathrm{NaCl}$, $60 \mathrm{mM} \mathrm{MgCl}$, and $20 \mathrm{mM}$ spermidine. If ribonucleotides are used at concentrations $>0.5 \mathrm{~m} M$ each, $\mathrm{MgCl}_{2}$ concentration should be increased to provide a free magnesium concentration of $4 \mathrm{mM}$.

4. $0.2 M$ Dithiothreitol (DTT): The solution is stored in small aliquots at $-20^{\circ} \mathrm{C}$. Aliquots are used only once. EDTA can be included at 0.5 $\mathrm{m} M$ to stabilize DTT solutions.

5. Ribonucleotides: Neutralized solutions of ribonucleotides are commercially available, or can be made up from dry powder (see Note 1). Ribonucleotide solutions can be stored at $-20^{\circ} \mathrm{C}$ for several months.

6. RNA polymerase stocks: The three RNA polymerases, SP6, T3, and T7, are available commercially. Store at $-20^{\circ} \mathrm{C}$.

7. RNA polymerase dilution buffer: $50 \mathrm{mM}$ Tris- $\mathrm{HCl}, \mathrm{pH} 8.1,1 \mathrm{~m} M$ DTT, $0.1 \mathrm{~m} M$ EDTA, $500 \mu \mathrm{g} / \mathrm{mL}$ bovine serum albumin (BSA) and $5 \%$ glycerol. Diluted enzyme is unstable and should be stored on ice for no more than a few hours.

8. Stop-mix: $1 \%$ sodium dodecyl sulfate (SDS), $10 \mathrm{~m} M$ EDTA and $1 \mathrm{mg} / \mathrm{mL}$ tRNA. The tRNA may be omitted.

9. TEN: $10 \mathrm{~m} M$ Tris- $\mathrm{HCl}, \mathrm{pH} 8.1,1 \mathrm{~m} M$ EDTA, and $100 \mathrm{~m} M \mathrm{NaCl}$.

10. Sample buffer (polyacrylamide/urea gels): $80 \%$ deionized formamide (see Note 2), $2 M$ urea, $0.1 \mathrm{X}$ TBE ( $8.9 \mathrm{~m} M$ Tris base, $8.9 \mathrm{~m} M$ boric acid, $0.2 \mathrm{~m} M$ EDTA), and $0.01 \%$ each of xylene cyanol and bromophenol blue. Use 1-2 $\mu \mathrm{L} / \mu \mathrm{L}$ of RNA in aqueous solution.

\subsection{Northern Blot Hybridization}

1. Formamide: Pure formamide is slowly hydrolyzed by water vapor to ammonium formate and therefore must be deionized (see Note 2). Store at $-20^{\circ} \mathrm{C}$.
2. Glyoxal: A $30 \%$ glyoxal solution $(6 M)$ is deionized by several incubations at room temperature with a mixed bed resin (AG501-X8, Bio-Rad), until the $\mathrm{pH}$ is $6.0-7.0$ and the conductivity of $3 \%$ glyoxal in water is below $30 \mu$ Siemens. Store at $-20^{\circ} \mathrm{C}$ in small aliquots.

3. Denaturation buffer: $1 M$ glyoxal in $50 \%$ dimethyl sulfoxide (DMSO) and $10 \mathrm{mM} \mathrm{Na} 2 \mathrm{HPO}_{4}, \mathrm{pH} 6.8$. Ethidium bromide can be included at a concentration of $50 \mu \mathrm{g} / \mathrm{mL}$ to visualize the rRNAs during electrophoresis.

4. 5X RNA sample buffer (RSB): $50 \%$ glycerol, $10 \mathrm{mM} \mathrm{Na}{ }_{2} \mathrm{HPO}_{4}, \mathrm{pH} 6.8$, and $0.4 \%$ bromophenol blue. Autoclave and store at $-20^{\circ} \mathrm{C}$ in small aliquots.

5. Transfer membrane: Nitrocellulose (Schleicher and Schuell, Keene, $\mathrm{NH}$ ) and nylon membranes (Hybond N, Amersham, Arlington Heights, IL or Biodyne A, Pall Biosupport, Glencove, NY) have been used successfully.

6. 50X Denhardt's solution: Dissolve $2 \mathrm{~g}$ of bovine serum albumin (fraction $\mathrm{V}$ ) in $80 \mathrm{~mL}$ of sterile water. Bring the $\mathrm{pH}$ to 3.0 with $2 \mathrm{~N} \mathrm{HCl}$, boil for $15 \mathrm{~min}$, and cool on ice for $10 \mathrm{~min}$. Bring the $\mathrm{pH}$ to 7.0 with $2 \mathrm{~N} \mathrm{NaOH}$ and add sterile water to $100 \mathrm{~mL}$. Autoclave a $100-\mathrm{mL}$ solution of $2 \%$ polyvinylpyrrolidone (K90, Fluka Chemie, AG, Buchs, Switzerland) and $2 \%$ Ficoll 400 (Pharmacia, Piscataway, NJ), and add to the $2 \%$ albumin solution.

7. Hybridization solution: $50 \%$ deionized formamide, $0.8 M \mathrm{NaCl}, 50 \mathrm{~m} M$ Na-PIPES, $\mathrm{pH} 6.8$, $2 \mathrm{~m} M$ EDTA, 0.1\% SDS, 2.5X Denhardt's solution, and $0.1 \mathrm{mg} / \mathrm{mL}$ sonicated and heatdenatured salmon sperm DNA. The hybridization solution is heated, filtered over $0.45 \mu \mathrm{m}$ Nalgene sterilization units or Millipore nitrocellulose filters, and kept at the hybridization temperature during prehybridization. The filtration step decreases nonspecific attachment of the probe to the membrane and degasses the solution.

8. $20 \mathrm{X}$ Standard saline citrate (SSC): $3 \mathrm{M} \mathrm{NaCl}$ and $0.3 M$ sodium citrate, $\mathrm{pH} 7.0$.

\subsection{RNase Protection}

1. Hybridization mixture for RNase protection: $80 \%$ deionized formamide (see Note 2), $0.4 M \mathrm{NaCl}, 40 \mathrm{~m} M$ Na-PIPES, $\mathrm{pH} 6.8$, and $1 \mathrm{~m} M$ EDTA. 
2. RNase digestion buffer: $300 \mathrm{~m} M \mathrm{NaCl}, 10 \mathrm{~m} M$ Tris- $\mathrm{HCl}, \mathrm{pH} 7.4$, and $4 \mathrm{mM}$ EDTA.

3. Pancreatic RNase: Make a $10 \mathrm{mg} / \mathrm{mL}$ solution in TE containing $10 \mathrm{mM} \mathrm{NaCl}$. Vials containing lyophilized RNases should be carefully open in a ventilated hood to avoid contamination. Boil for $15 \mathrm{~min}$ and slowly cool to room temperature. Store in aliquots at $-20^{\circ} \mathrm{C}$.

4. T1 RNase: Make a $1 \mathrm{mg} / \mathrm{mL}$ solution in TE. Adjust the $\mathrm{pH}$ to 7.0 . Store in aliquots at $-20^{\circ} \mathrm{C}$.

5. Proteinase K: Dissolve the enzyme at 20 $\mathrm{mg} / \mathrm{mL}$ in water and store in aliquots at $-20^{\circ} \mathrm{C}$.

\section{Methods}

\subsection{Preparation of Riboprobes}

3.1.1. Linearized Plasmid Templates for Runoff Transcription

1. Subclone the desired gene fragment in a transcription vector (see Note 3).

2. Isolate plasmid DNA by alkaline lysis from a $30-100 \mathrm{~mL}$ saturated culture. Plasmid DNAs are purified by $\mathrm{CsCl} /$ ethidium bromide centrifugation or by precipitation with polyethyleneglycol (see Note 4).

3. Linearize $2-20 \mu \mathrm{g}$ of plasmid DNA with an appropriate restriction enzyme (see Note 5). Verify the extent of digestion by electrophoresis of an aliquot $(0.2-0.5 \mu \mathrm{g}$ of DNA) on an agarose minigel in the presence of ethidium bromide $(0.5 \mu \mathrm{g} / \mathrm{mL})$ (see Note 6$)$.

4. Purify the restricted DNA by two extractions with phenol/chloroform/isoamyl alcohol (25/24/1 by vol), and remove residual phenol by one extraction with chloroform (24/1 by vol). Precipitate the DNA with ethanol. If little DNA is present (below $5 \mu \mathrm{g}$ ), add $10 \mu \mathrm{g}$ of glycogen (Boehringer Mannheim, Mannheim, Germany) as a carrier; this carrier has no adverse effect in the transcription reactions. After washing the ethanol pellet, the DNA is dried in air and resuspended in TE at $1 \mu \mathrm{g} / \mu \mathrm{L}$.

\subsubsection{Synthetic and PCR-Derived Templates}

The major limitation in using restriction enzymes to clone inserts and to linearize plasmid templates is that appropriate sites are not always available. Furthermore, the transcripts will almost always contain $5^{\prime}$ and 3 ' portions that differ from those of endogenous RNA. One possibility to circumvent these difficulties is based on the transcription of small DNA fragments obtained by annealing of synthetic oligodeoxynucleotides $(6,8)$. An alternative and more general approach generates the transcription templates via PCR amplification of plasmid DNA. In theory, such templates could direct the synthesis of virtually any RNA sequence.

1. Design the 5 primer, which has a composite sequence: its 5 ' portion is constituted by a minimal $\mathrm{T} 7$ promoter, and its 3 ' portion corresponds to the beginning of the transcript (see Note 7). Six to ten nucleotides (nt) are usually sufficient to prime DNA synthesis on the plasmid template.

2. Design the $3^{\prime}$ primer, which is usually $17-20-n t$ long and defines the 3 ' end of the transcript (see Note 8).

3. PCR amplify $2-50 \mathrm{ng}$ of plasmid DNA in a total volume of $100 \mu \mathrm{L}$. Verify that a DNA fragment of the expected size has been amplified, and estimate the amount of DNA by comparison with known standards.

4. Purify the DNA as described in Subheading 3.1.1., step 4 and resuspend in TE at the appropriate concentration. The PCR-derived templates are transcribed at lower DNA concentrations than plasmids to maintain the molar ratio of enzyme to promoter; I use $3 \mu \mathrm{g} / \mathrm{mL}$ for a 100 -bp fragment.

\subsubsection{Basic Transcription Protocol for Radioactive Probes}

1. Assemble the transcription mixture to a total volume of $10 \mu \mathrm{L}$ by adding in the following order: water (as required), $1 \mu \mathrm{L}$ of $10 \mathrm{X} \mathrm{TB}$, $0.5 \mu \mathrm{L}$ of bovine serum albumin $(2 \mathrm{mg} / \mathrm{mL})$, $0.5 \mu \mathrm{L}$ of $0.2 M$ DTT, $0.25 \mu \mathrm{L}$ of placental RNase inhibitor $(40 \mathrm{U} / \mu \mathrm{L}), 1 \mu \mathrm{L}$ of a $5 \mathrm{mM}$ solution of each ribonucleotide, i.e., ATP, GTP, CTP, $5 \mu \mathrm{L}$ of $\alpha-\left[{ }^{32} \mathrm{P}\right]-\mathrm{UTP}$ ( $400 \mathrm{Ci} / \mathrm{mmol}, 10$ $\mathrm{mCi} / \mathrm{mL}), 1 \mu \mathrm{L}$ of restricted plasmid DNA template, and $0.25-0.75 \mu \mathrm{L}$ of RNA polymerase (see Notes 9 and 10).

2. Incubate $40 \mathrm{~min}$ at $37^{\circ} \mathrm{C}$ for $\mathrm{T} 7$ and $\mathrm{T} 3$ polymerases or $40^{\circ} \mathrm{C}$ for SP6 polymerase. After addition of the same number of units of enzyme (see Note 10), incubate for a further $40 \mathrm{~min}$. 
3. Degrade the template with RNase-free DNase (1 U/ $\mu \mathrm{g}$ of DNA) for $20 \mathrm{~min}$ at $37^{\circ} \mathrm{C}$.

4. Stop the reaction by adding $40 \mu \mathrm{L}$ of stop-mix.

5. After two extractions with phenol/chloroform, in which the organic phases are back-extracted with $50 \mu \mathrm{L}$ of TEN, the combined aqueous phases are purified from unincorporated nucleotides by spun-column centrifugation. The spun-column is prepared by filling disposable columns (QS-Q, Isolab, Hörth, Germany) with a sterile $50 \%$ slurry of G-50 Sephadex (Pharmacia) in TEN followed by centrifugation for $5 \mathrm{~min}$ at $1200 \mathrm{rpm}(200 \mathrm{~g})$. The samples are carefully deposited on top of the dried resin, and the column is placed in a sterile conical centrifuge tube. After one centrifugation for $5 \mathrm{~min}$ at 1200 $\mathrm{rpm}, 200 \mu \mathrm{L}$ of TEN is deposited on top of the resin and the column recentrifuged. The eluted RNA $(200-400 \mu \mathrm{L})$ is ethanol precipitated and resuspended in water (see Note 11).

6. Measure the incorporation efficiency by counting an aliquot (see Note $\mathbf{1 2}$ for calculations and for modifications of the basic protocol).

7. The size of the transcript may be verified by electrophoresis in polyacrylamide/urea gels (see Note 13).

\subsection{Northern Blot Hybridization}

The use of riboprobes in RNA blot hybridizations follows the same general principles as that for DNA probes. The major disadvantage in using double-stranded DNA probes results from self-annealing, which decreases the availability of DNA probes to bind to the immobilized target; this is particularly critical with heterologous probes, in which the reannealed probe may displace incompletely matched hybrids. Self-annealing of course does not occur with single-stranded RNA probes. Most difficulties encountered with riboprobes stem from the increased thermal stability of RNA:RNA hybrids. Thus, cross-hybridization of GC-rich probes to rRNAs can generate unacceptable backgrounds. This problem is often solved by increasing the stringency of hybridization, as illustrated in Fig. 1B. Alternatively, the template may have to be shortened to remove $\mathrm{GC}$-rich regions from the probe.
1. Denature the sample in $8 \mu \mathrm{L}$ of denaturation buffer for $15-30 \mathrm{~min}$ at $50^{\circ} \mathrm{C}$. Add $2 \mu \mathrm{L}$ of 5X RSB and electrophorese in 0.7-2\% agarose gels in $10 \mathrm{mM} \mathrm{Na} \mathrm{HPO}_{4}$, pH 6.8. The buffer should be circulated with a peristaltic pump, so that the $\mathrm{pH}$ near the electrodes remains neutral.

2. Transfer the RNAs by capillarity onto a membrane (see Note 14).

3. Fix the RNA by incubating the blots at $80^{\circ} \mathrm{C}$ under vacuum. This step is essential to remove glyoxal covalently fixed to guanine residues in the RNA.

4. UV-crosslinking is often used to improve RNA retention, although irradiation may increase background hybridization (see Fig. 1A and Note 15).

5. Prehybridize the blots for $3-12 \mathrm{~h}$ in hybridization solution. Use $200 \mu \mathrm{L}$ of the solution per $\mathrm{cm}^{2}$ of membrane.

6. Dilute the probe in hybridization solution (25-50 $\mu \mathrm{L} / \mathrm{cm}^{2}$ of membrane), then add to the membrane. I frequently hybridize $2-3$ filters per bag. Hybridize at the appropriate temperature $\left(58-68^{\circ} \mathrm{C}\right.$, see Fig. $1 \mathrm{~B}$ and Note 16), usually for 12-18 h (see Note 17).

7. Wash the membranes twice for $10-20 \mathrm{~min}$ at the hybridization temperature with $100 \mu \mathrm{L} / \mathrm{cm}^{2}$ of 3X SSC, and 2X Denhardt's solution, and then three times with $0.2 \mathrm{X}$ SSC, $0.1 \%$ SDS, and $0.1 \%$ sodium pyrophosphate at the appropriate temperature (see Fig. 1B and Note 17).

8. Expose to autoradiographic film. As long as the membranes are not allowed to dry, they can be further washed at increased stringencies to reduce background.

\subsection{RNase Protection}

This assay is based on solution hybridization and on the resistance of RNA:RNA hybrids against single-strand specific RNases. A ${ }^{32} \mathrm{P}$-labeled probe is synthesized that is partially complementary to a portion of the target RNA. It is hybridized in excess to the target so that all complementary sequences are driven into the labeled RNA:RNA hybrid. Unhybridized probe and any single-stranded region of the hybridized probe are then removed by RNase digestion. The 
A

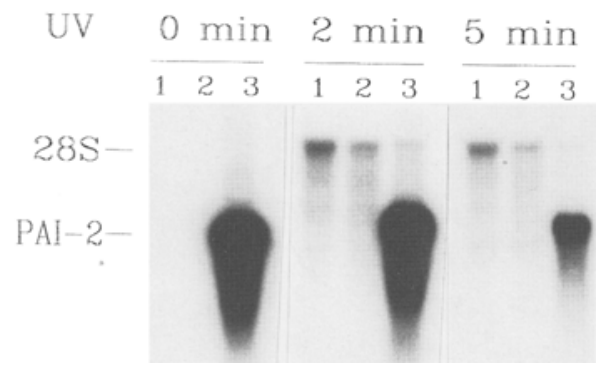

B

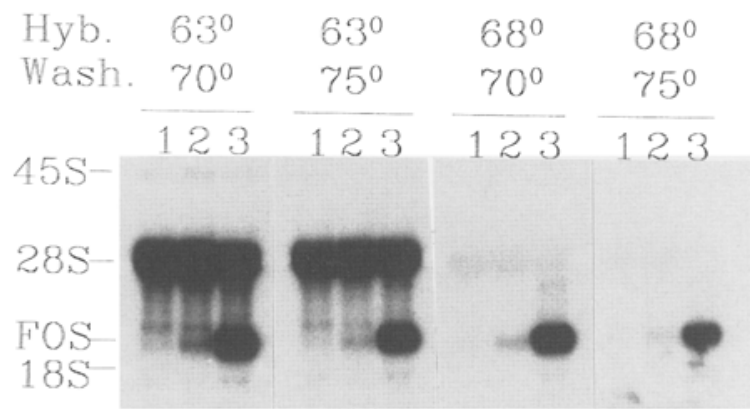

Fig. 1. Northern blot hybridization with riboprobes. (A) Effect of UV crosslinking. Northern blot hybridization of PAI-2 mRNA in murine total cellular RNA with an homologous cRNA probe. Lanes 1 and $2: 5 \mu \mathrm{g}$ of placental RNA (15.5 and 18.5 d gestation), that do not contain detectable levels of PAI-2 mRNA. Lane 3: $1 \mu \mathrm{g}$ of LPS-induced macrophage RNA, an abundant source of PAI-2 mRNA (29). All samples were electrophoresed and transferred together. After cutting the membrane, each filter was UV-treated as described. The filters were hybridized at $58^{\circ} \mathrm{C}$, washed at $70^{\circ} \mathrm{C}$, and exposed together. Cross-hybridization of the probe to 28S rRNA is more pronounced after UV irradiation, and specific hybridization is decreased after $5 \mathrm{~min}$ of UV exposure. (B) Effect of hybridization temperature. Northern blot hybridization of c-fos mRNA in rat total cellular RNA with a murine v-fos cRNA probe. Lane 1: uninduced cells. Lane 2: partially induced cells. Lane 3: fully induced cells (M. Prentki and D. Belin, unpublished). All samples were electrophoresed and transferred together. The filters, which were not UV cross-linked, were hybridized and washed in parallel at the indicated temperatures. The four filters were exposed together. Cross-hybridization of the probe to $28 \mathrm{~S}$ rRNA was essentially abolished by hybridizing at $68^{\circ} \mathrm{C}$. Some specific signal was lost with the $75^{\circ} \mathrm{C}$ stringency wash.

"protected" probe is then detected and quantitated on a denaturing polyacrylamide gel. It can be used to map the ends of RNA molecules or exon-intron boundaries. It also provides an attractive and highly sensitive alternative to Northern blot hybridization for the quantitative determination of mRNA abundance.

RNase protection has a number of advantages. First, solution hybridization tolerates high RNA input (up to $60 \mu \mathrm{g}$ of total RNA), and is not affected by the efficiency of transfer on membranes or by the availability of membrane-bound RNAs. Second, the signal to noise ratio is much more favorable, since cross-hybridizing RNAs yield only short protected fragments. Third, a significant fraction of mRNAs is often partially degraded during RNA isolation; in Northern blots, this generates a trail of shorter hybridizing species, which reduces the sensitivity of detection. Finally, the detection of hybridized probes on sequencing gels is much more sensitive because the width of the bands is less than a tenth of those of intact RNAs in agarose gels.

Only two features of Northern blots are lost in RNase protection assays: complete size determination of target RNAs and multiple use of each sample.

1. Linearize the plasmid DNA template as described in Subheading 3.1.1. (see Note 18).

2. Transcribe the template as described in Subheading 3.1.3. The amount of labeled ribonucleotide may be varied (see Note 19).

3. An optional step is to purify the full-length transcripts by electrophoresis (see Note 20). Separate the transcript on a preparative 5-6\% polyacrylamide/urea gel (gel thickness: $0.4-1.0 \mathrm{~mm}$ ). Cover the wet gel with Saran Wrap ${ }^{\mathrm{TM}}$ and expose for $30 \mathrm{~s}$ to $2 \mathrm{~min}$ at room temperature to localize the full-length transcript. Cut the exposed band on the film with a razor blade. After aligning the cut film on the gel, excise the gel band with a sterile blade. The cut gel should be reexposed to verify that the correct band has been excised.

4. Elute the RNA from the gel either by diffusion or electroelution.

a. Incubate the gel fragment in an Eppendorf tube in $500 \mu \mathrm{L}$ of $0.5 M$ ammonium acetate, $1 \%$ SDS, and $20 \mu \mathrm{g} / \mathrm{mL}$ tRNA for $1-3 \mathrm{~h}$ at $37^{\circ} \mathrm{C}$, or overnight at $4^{\circ} \mathrm{C}$. The eluate and residual gel can be counted to ensure that more than $60 \%$ of the RNA is eluted. After two 
extractions with phenol/chloroform, recover the eluted RNA by ethanol precipitation.

b. Electroelute for $1-2 \mathrm{~h}$ at $30 \mathrm{~V} / \mathrm{cm}$ in $0.1 \mathrm{X}$ TBE in a sterile dialysis bag, after which invert the polarity for $30 \mathrm{~s}$ to detach the eluted RNA from the membrane. Purify the eluate by two phenol/chloroform extractions and ethanol precipitation with a known amount of tRNA carrier. This procedure is very sensitive to RNase degradation.

5. Resuspend the probe in water at $1-2 \mathrm{ng} / \mu \mathrm{L}$. Add $1 \mu \mathrm{L}$ of probe to $29 \mu \mathrm{L}$ of hybridization mixture for each assay. The exact amount of probe is not critical, since it is in excess of its specific target (see Notes 19 and 21).

6. Lyophilize or ethanol precipitate the sampie RNAs (see Note 22). Resuspend in $30 \mu \mathrm{L}$ of complete hybridization mixture including probe, heat for $2 \mathrm{~min}$ at $90^{\circ} \mathrm{C}$, and incubate overnight, usually at $45^{\circ} \mathrm{C}$ (see Notes 23 and 24).

7. Cool the samples on ice and add $300 \mu \mathrm{L}$ of RNase digestion buffer. Digest for $1 \mathrm{~h}$ at $25^{\circ} \mathrm{C}$ with pancreatic RNase, which cleaves after uracil and cytosine residues, with $\mathrm{T} 1$ RNase, which cleaves after guanine residues, or with both RNases (see Notes 25 and 26).

8. Add $20 \mu \mathrm{L}$ of $10 \%$ SDS, and degrade the enzyme(s) with $0.5 \mu \mathrm{L}(10 \mu \mathrm{g})$ of proteinase $\mathrm{K}$ for $10-20$ $\mathrm{min}$ at $37^{\circ} \mathrm{C}$. Extract once with phenol/chloroform, and precipitate the RNAs with ethanol with $10 \mu \mathrm{g}$ of carrier tRNA (see Note 27).

9. Resuspend the RNAs in sample buffer, denature the hybrids for $2 \mathrm{~min}$ at $90^{\circ} \mathrm{C}$, and electrophorese in polyacrylamide/urea sequencing gels. Alternatively, the hybrids may be analyzed on nondenaturing polyacrylamide gels. Fix the gels with $20 \%$ ethanol and $10 \%$ acetic acid to remove the urea, dry, and autoradiograph (see Note 28).

\section{Notes}

1. Powdered ribonucleotides should be resuspended in water, neutralized to $\mathrm{pH} 7.0$ with $1 M$ $\mathrm{NaOH}$ or $\mathrm{HCl}$, and adjusted to the desired concentration by measuring the UV absorbance of appropriate dilutions:

a. $100 \mathrm{mM}$ ATP: 1540 absorbance units at $259 \mathrm{~nm}$.

b. $100 \mathrm{~m} M$ GTP:1370 absorbance units at $253 \mathrm{~nm}$.

c. $100 \mathrm{~m} M$ CTP: 910 absorbance units at $271 \mathrm{~nm}$.

d. $100 \mathrm{~m} M$ UTP: 1000 absorbance units at $262 \mathrm{~nm}$.
The integrity of ribonucleotide triphosphate solutions can be verified by thin-layer chromatography on PEI-cellulose (PEI-CEL300). The resin is first washed with water by ascending chromatography to remove residual UVabsorbing material and dried. Ribonucleotides 10-30 nmol are deposited on the resin, which is then resolved by ascending chromatography with $0.5 M \mathrm{KH}_{2} \mathrm{PO}_{4}$, adjusted to $\mathrm{pH} 3.5$ with $\mathrm{H}_{3} \mathrm{PO}_{4}$. After drying, the ribonucleotides are detected by UV-shadowing at $254 \mathrm{~nm}$.

2. To deionize formamide, incubate at $-80^{\circ} \mathrm{C}$ until $75-90 \%$ of the solution has crystallized. Discard the liquid phase, thaw and incubate at $4^{\circ} \mathrm{C}$ for several hours with a mixed bed resin (AG501-X8, Biorad). Use a Teflon ${ }^{\mathrm{TM}}$-covered magnet that has been freed of RNase by treatment with $0.1 M \mathrm{NaOH}$ for $10 \mathrm{~min}$, and rinsed with water and with crude formamide. Check the conductivity, which should be below $20 \mu$ Siemens. Filter the solution onto sterile paper (Whatman, LS-14) over a sterile funnel. The absorbance at $270 \mathrm{~nm}$ should be below 0.2 .

3. All the vectors that are commercially available consist of high copy number Escherichia coli plasmids derived from ColE 1. The original plasmids (pSP64 and pSP65, Promega, Madison WI) contained only one SP6 promoter located upstream of multiple cloning sites (MCS) (2). In the second generation of plasmids, two promoters in opposite orientation flank the MCS to allow transcription of both strands of inserted DNA fragments. The pGEM ${ }^{\mathrm{TM}}$ series (Promega) contain SP6 and T7 promoters (5), whereas the $\mathrm{pBluescript}^{\mathrm{TM}}$ series (Stratagene Cloning Systems, Inc., La Jolla, CA) contain T7 and T3 promoters. The choice of plasmid is mostly a matter of personal preference, although it can be influenced by the properties of individual sequences. For instance, we have frequently observed premature termination with SP6 transcripts. The nature of the termination signals is not completely understood $(4,9)$, and their efficiency can be more pronounced when one ribonucleotide is present at suboptimal concentration (see Note 13). The problem has sometimes been solved by recloning the inserts in front of a $\mathrm{T} 7$ or $\mathrm{T} 3$ promoter. The partial recognition of T7 (T3) promoters by T3 (T7) poly- 
merases may result in the transcription of both strands when the ratio of enzyme to promoter is very high. This can be a source of artifacts, particularly when the templates are linearized inside the cloned inserts.

4. It is possible to use plasmid DNA from "minipreps," although transcription efficiency can be reduced, particularly with SP6 polymerase. The RNA present in the minipreps is digested with pancreatic RNase $(20 \mu \mathrm{g} / \mathrm{mL})$, which is removed during purification of the linearized templates. Spun-column centrifugation of the digested minipreps can improve transcription efficiency.

5. Since RNA polymerases can initiate transcription unspecifically from $3^{\prime}$ protruding ends $(4,10)$, restriction enzymes that generate $5^{\prime}$ protruding or blunt ends are usually preferred. If the only available site generates $3^{\prime}$ protruding ends, the DNA can be blunt-ended by exonucleolytic digestion with T4 DNA polymerase or with the Klenow fragment of DNA polymerase I. Restriction with enzymes that cut the plasmids more than once may also be used, provided that the promoter is not separated from the insert.

6. The plasmids must be linearized as extensively as possible. Since circular plasmids are efficient templates, their transcription by the highly processive enzymes may yield RNA molecules that can be up to $20 \mathrm{~kb}$ long and thus incorporate a significant portion of the limiting ribonucleotide.

7. There are constraints on the 5 '-sequence of transcripts since the sequence immediately downstream of the start site is necessary for the transition from an abortive initiating cycling mode to the elongation mode. The first $6 \mathrm{nt}$ have a strong influence on promoter efficiency; in particular, the presence of uracil residues are usually detrimental $(6,8)$. It may be necessary, therefore, to include in the 5'-end of the transcripts 5-6 bases that differ from those present in natural RNAs. My colleagues and I have used a number of composite $\mathrm{T} 7$ promoters, whose efficiency is summarized below. In addition to the promoter sequence ( -17 to -1 : 5'-TAATACGACTCACTATA) at the 5' end, the first $6 \mathrm{nt}$ of the templates are:

\section{Efficient promoters \\ GGGAGA (T7 consensus) GGGCGA (pBS plasmids) \\ Inefficient promoters GTTGGG (5\% efficiency) GCTTTG ( $1 \%$ efficiency) GCCGAA}

Composite 5' primers with the SP6 promoter sequence have also been used successfully. There are also constraints on the $5^{\prime}$ sequence of the transcripts, but the optimal sequences (GAATA, GAACA, and GAAGA) are different than those with $\mathrm{T} 7$ polymerase (11-13).

8. The 3' end of the transcripts should be exactly defined by the 5 ' end of the downstream primer. However, template-independent addition of 1$2 \mathrm{nt}$ during transcription usually generates populations of RNAs with different 3 ' ends. The proportion of each residue at the $3^{\prime}$ end may depend on context and is influenced by the relative concentration of each ribonucleotide, limiting ribonucleotide being less frequently incorporated $(2,6,8,14)$.

9. The order of addition of components may be changed. Remember that dilutions of RNasin are very unstable in the absence of DTT, and that DNA should not be added to undiluted 10X TB. The temperature of all components must be at least at $25^{\circ} \mathrm{C}$, to avoid precipitation of the DNA:spermidine complex. Since the radioactive nucleotides, which constitute half of the reactions, are provided in well-insulated vials, they can take up to 10-15 min after thawing to reach an acceptable temperature. I routinely incubate all components, except the RNasin and the polymerase, at $30^{\circ} \mathrm{C}$ for $15-20 \mathrm{~min}$. When more than one probe is to be synthesized, a reaction mixture with all components is added to the DNA template. It is possible to reduce the total volume to $8 \mu \mathrm{L}$, in order to conserve materials; however, since the enzymes are very sensitive to surface denaturation, these incubations are done in $400-\mu \mathrm{L}$ vials.

10. For SP6 polymerase, use 5-10 $U / \mu$ g of plasmid DNA (size: 3-4 kbp). For T7 and T3 polymerases, use 10-20 U/ $\mu \mathrm{g}$ of plasmid DNA.

11. The purification step (Subheading 3.1.3., step 4) may not be required, and some investigators use the transcription mixtures directly in hybridization assays. However, low backgrounds, consistency, and quantitation of the 
newly synthesized RNAs probably justify the additional time and effort.

12. More than $50 \%$ of the labeled ribonucleotide is routinely incorporated, and often greater than $80 \%$. An input of $50 \mu \mathrm{Ci}$ may therefore yield up to $4 \times 10^{7}$ Cerenkov-cpm of RNA. This represents $100 \mathrm{pmol}$ of UMP and, assuming no sequence bias (i.e., $25 \%$ of residues are uracil residues), $130 \mathrm{ng}$ of RNA (specific activity: $3 \times 10^{8}$ Cerenkov-cpm $/ \mu \mathrm{g}$ ).

Similar results are obtained with labeled CTP and GTP, although GTP rapidly loses its incorporation efficiency on storage. ATP is not routinely used because of its higher apparent $K_{m}$ for SP6 polymerase on linear templates $(2,15)$. UTP is particularly stable and can be used even after several weeks, once radioactive decay is taken into account. With each labeled ribonucleotide, the initial concentration must be $\geq 12.5 \mu M$ to ensure efficient incorporation and to prevent polymerase pausing. Transcripts destined to be translated must incorporate a $5^{\prime} 7 \mathrm{mG}$ cap structure. This is usually achieved by performing the transcription in the presence of $500 \mu M$ of a cap analog dinucleotide and $50 \mu M$ GTP. Since the cap analog can also be used during elongation, labeled GTP should not be used to calculate incorporation efficiency. A variety of other labeled or of unlabeled probes may also be made for use in in situ hybridization (see refs. 16-20).

For the synthesis of large quantities of RNA (>10 RNA transcripts/DNA template molecule), each ribonucleotide is added at a final concentration of $0.5-1 \mathrm{mM}$; trace amounts of labeled UTP should be included to calculate transcription efficiency and to verify the size of the transcript. Total volume is increased to reduce the concentration of plasmid DNA to $30-50 \mu \mathrm{g} / \mathrm{mL}$. Additional modifications of the standard protocol have been described, and include the use of HEPES-KOH, $\mathrm{pH} 7.5$, at $120 \mathrm{~m} M$ (SP6 polymerase), $200 \mathrm{mM}$ (T7 polymerase), or $300 \mathrm{~m} M$ (T3 polymerase) (21). Furthermore, the T4 gene 32 protein can increase transcription efficiency when added at $10 \mu \mathrm{g} / \mu \mathrm{g}$ of template DNA (D. Caput, personal communication). It has been recently reported that a reduction of premature termina- tion and an increased synthesis of large fulllength transcripts (size $>1 \mathrm{~kb}$ ) can be obtained by performing the transcription at $30^{\circ} \mathrm{C}$ or at room temperature $(4,22)$.

13. Large transcripts that do not enter the polyacrylamide gel are diagnostic of incompletely linearized templates. Small transcripts are indicative of extensive pausing or premature termination. In addition to the natural $\mathrm{T} 7 \mathrm{ter}$ mination signal, a site located in the coding region of the parathyroid hormone (PTH) gene has been extensively characterized $(23,24)$. Mutant T7 RNA polymerases that show reduced termination at natural sites have been constructed by Drs. D. H. Lyakhov and W. T. McAllister (SUNY, Brooklyn, NY).

14. Hybridization of dot-blots is often used to quantitate mRNA levels with a large number of samples. To accurately quantitate specific hybrids, it is necessary to include as negative control total RNA from cells that do not express the transcript under examination.

15. The intensity provided by transilluminators, a common source of UV light, varies with time, and excessive crosslinking can severely reduce hybridization efficiency (Fig. 1A). Furthermore, UV-crosslinking can increase cross-hybridization to rRNAs, possibly by inducing covalent cross-linking with the probe. UV irradiation should thus be limited to membranes subjected to multiple rounds of hybridization. An apparatus commercially available from Stratagene provides a means to control the dose of UV. The appropriate dose of UV is probably different for different membranes and is broader for wet than for dry membranes.

16. The major variables in optimizing signal-tonoise ratio are the temperature of hybridization and the temperature of the stringency washes (Fig. 1B). Many probes can be hybridized at $58^{\circ} \mathrm{C}$, although the temperature must be increased to $68^{\circ} \mathrm{C}$ for certain pairs of probe and target RNAs. Stringency washes are usually performed at 70 or $75^{\circ} \mathrm{C}$. It is difficult to increase stringency much further, since most water baths cannot maintain accurate temperatures at or above $80^{\circ} \mathrm{C}$. For the detection of DNA targets, hybridization is usually performed at $42^{\circ} \mathrm{C}$ and the stringency washes are at $65^{\circ} \mathrm{C}$. 
17. RNA probes are usually $200-800-n t$ long. With 600-nt-long RNA probes, a hybridization plateau is achieved in $20 \mathrm{~h}$ at $58^{\circ} \mathrm{C}$ with $2.5 \mathrm{ng} / \mathrm{mL}$ of probe. This represents an input of $7.5 \times 10^{5}$ Cerenkov-cpm $/ \mathrm{mL}$. The probe concentration can be increased to $10 \mathrm{ng} / \mathrm{mL}$, and the hybridization time decreased to $5 \mathrm{~h}$ without increasing background.

18. The probes should be $100-400$-nt long, and should include at least $10 \mathrm{nt}$ that are not complementary to the target RNA. Residual template DNA generally produces a trace of full-length protected probe that must be distinguishable from the fragment protected by the target RNA (Fig. 2).

19. It is often useful to decrease the specific activity of the probe: more RNA is synthesized at the resulting higher ribonucleotide concentration, the probes are less susceptible to radiolysis, and less radioactivity is used. The guideline in Table 1 can be used to alter the specific activity of the probes according to the sensitivity required.

20. Purification is often necessary for maximal sensitivity or for mapping purposes. The transcription reaction can be directly loaded on the preparative gel after DNase digestion of the template, provided that enough EDTA is present in the sample buffer to chelate all the magnesium. Omitting the DNase digestion of the template results in higher amounts of fully protected probe in the assay.

21. The probe must be in excess of the target RNA (see Fig. 2A). An input of 1-2 ng of a 300-nt probe in a total volume of $30 \mu \mathrm{L}$ will drive the hybridization of target RNA to completion (4-8 $T_{1 / 2}$ ) in 12-16 h. Shorter hybridizations can be performed but require higher probe input $\left(R_{O}\right)$ to achieve the same extent of saturation, i.e., to maintain the $R_{O} \times \mathrm{T}_{1 / 2}$ value.

22. To facilitate the RNase digestion step, each sample should contain the same amount of total RNA. For very low abundance target RNA, the amount of sample RNA may be increased up to $60 \mu \mathrm{g}$. Inequalities should be eliminated by addition of tRNA. A negative control sample, containing only tRNA, is always included (Fig. 2A, lane 4; Fig. 2B, lane 3).

23. The temperature of hybridization must be reduced to detect small or very AU-rich protected frag-
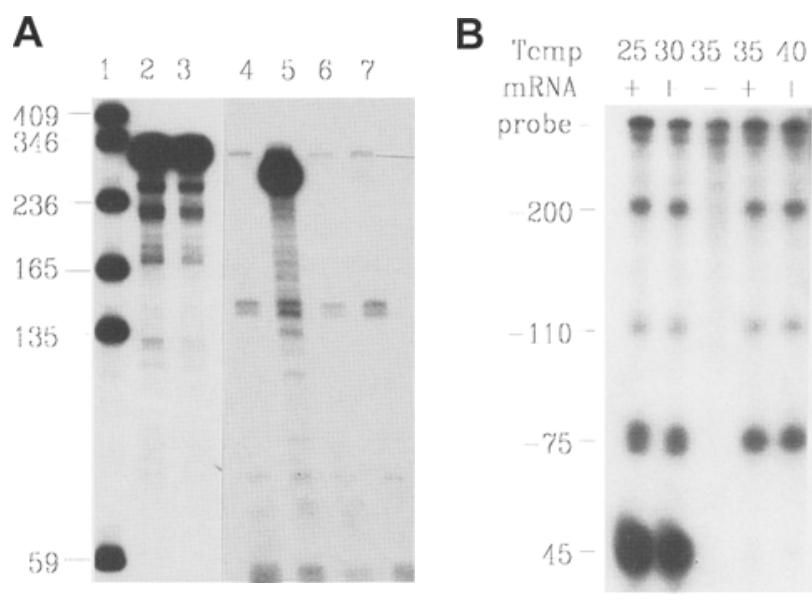

Fig. 2. RNase protection assay. (A) Discrimination between target-specific signal and complete probe protection by residual DNA. Detection of PN-I mRNA in total RNA from murine tissues (25). The probe (310nt long) was gel purified. Lane 1: Size markers. Lane 2: purified probe. Lane 3: probe hybridized and processed without RNase digestion. This part of the gel was autoradiographed for $6 \mathrm{~h}$. Lane 4: control hybridization with $10 \mu \mathrm{g}$ of tRNA; traces of fully protected probe are visible. Lane 5: $10 \mu \mathrm{g}$ of RNA from seminal vesicles, an abundant source of PN-I mRNA; the specific protected fragment is 260-nt long. Lane 6: $10 \mu \mathrm{g}$ of liver RNA, which does not contain detectable levels of PN-I mRNA. Lane 7: $10 \mu \mathrm{g}$ of testis RNA, which contains trace levels of PN-I mRNA. This part of the gel was autoradiographed for $24 \mathrm{~h}$. (B) Effect of hybridization temperature on the detection of short complementary RNAs. The 5' ends of phage T4 gene 32 transcripts in total RNA from bacteria carrying a gene 32 expression cassette were mapped by hybridization to a cRNA probe containing $400 \mathrm{nt}$ of gene 32 upstream sequences (23). The probe was not gel purified, and hybridizations were performed at the indicated temperatures. Fully protected probe results from incomplete DNase digestion of the template, and is also visible in the control hybridization without target RNA. The 44-nt-protected fragment is no longer detected above $30^{\circ} \mathrm{C}$.

ments. For instance, a 44-nt fragment of a phage $\mathrm{T} 4$ gene 32 transcript (containing 35 $\mathrm{A} / \mathrm{U}$ and $9 \mathrm{C} / \mathrm{G}$ ) was only protected by performing the hybridization at $25-30^{\circ} \mathrm{C}$ (Fig. 2B) (26).

24. Alternatively, the probe and target RNAs are made up in $9 \mu \mathrm{L}$ of TE, heated for $2 \mathrm{~min}$ at $90^{\circ} \mathrm{C}$, and chilled on ice. After the addition of $1 \mu \mathrm{L}$ of 
Table 1

Specific Activity of RNase Protection Probes

\begin{tabular}{lccl}
\hline $\begin{array}{l}\text { Target RNA } \\
\text { abundance }\end{array}$ & Unlabeled UTP & \multicolumn{1}{c}{$\left[{ }^{32} \mathrm{P}\right]$-UTP } & \multicolumn{1}{c}{ Probe/sample $^{a}$} \\
\hline High & $100 \mu \mathrm{M}$ & $2.5 \mu M, 10 \mu \mathrm{Ci}$ & 6-12 Kcpm \\
Moderate & $10 \mu M$ & $2.5 \mu M, 10 \mu \mathrm{Ci}$ & $60-120 \mathrm{Kcpm}$ \\
Low & - & $12.5 \mu M, 50 \mu \mathrm{Ci}$ & $300-600 \mathrm{Kcpm}$ \\
\hline
\end{tabular}

${ }^{a}$ The amount of probe required per sample for the detection of the target (see Note 21).

$3 M \mathrm{NaCl}, 0.2 M$ Tris-HCI, $\mathrm{pH} 7.4$, and $20 \mathrm{~m} M$ EDTA, the hybridization is carried out for $30-60 \mathrm{~min}$ at $70^{\circ} \mathrm{C}$. Since the probe concentration is higher, there is no formamide, and the incubation temperature is higher, the hybridization is driven to completion more rapidly. The RNase digestion can be performed in $50-100 \mu \mathrm{L}$ (27; J. Curran, personal communication).

25. The amount of RNase is determined by the total amount of RNA present in the samples, including that contributed by the probe. I usually add $0.5 \mu \mathrm{g}$ of pancreatic RNase and/or $0.25 \mu \mathrm{g}$ of $\mathrm{T} 1 \mathrm{RNase}$ per microgram RNA. In most cases, digestion with pancreatic RNase alone is sufficient. When the probe and the target RNAs are from different species, the extent of homology can be sufficient to generate discrete protected fragments, particularly if digestion is performed with RNase T1 only. The temperature of digestion can be increased to $30-37^{\circ} \mathrm{C}$, although this often leads to partial cleavages within the RNA:RNA hybrids.

26. To ensure that the probe remains intact during hybridization, it may be useful to include a parallel control that is hybridized and processed without RNase treatment (Fig. 2A, lanes 2 and 3).

27. RNases may also be inactivated by the addition of $330 \mu \mathrm{L}$ of $4 M$ guanidinium thiocyanate, $25 \mathrm{mM}$ sodium citrate, $\mathrm{pH} 7.0$, and $1 M \beta$-mercaptoethanol. Add $20 \mu \mathrm{g}$ of tRNA, precipitate the RNAs with $660 \mu \mathrm{L}$ of isopropanol, and centrifuge immediately for $15 \mathrm{~min}$ at $13,000 \mathrm{~g}(28$; P. A. Menoud, personal communication).

28. Minor shorter protected fragments are often detected, and they may complicate the interpretation of mapping assays (29). To distinguish between digestion artifacts and rare target RNAs that are only partially complementary to the probe, a synthetic sense transcript fully complementary to the probe may be used as a control target RNA (30). A sense RNA can be included as a reliable external control (31).

\section{Acknowledgments}

I thank P. Vassalli for his early encouragement to use riboprobes for detecting rare mRNAs. Over the last few years, many colleagues, students, and technicians have contributed to the methods outlined in this article, including $M$. Collart, N. Busso, J.-D. Vassalli, H. Krisch, S. Clarkson, J. Huarte, S. Strickland, P. Sappino, M. Pepper, A. Stutz, G. Moreau, D. Caput, M. Prentki, W. Reith, J. Curran, P. A. Menoud, A. Nichols, P. Gubler, F. Silva, V. Monney, D. Gay-Ducrest, and N. Sappino. Research is supported by grants from the Swiss National Science Foundation and by the Canton de Genève.

\section{References}

1. Butler, E. T. and Chamberlin, M. J. (1984) Bacteriophage SP6-specific RNA polymerase. J. Biol. Chem. 257, 5772-5788.

2. Melton, D. A., Krieg, P. A., Rebagliati, M. R., Maniatis, T., Zinn, K., and Green, M. R. (1984) Efficient in vitro synthesis of biologically active RNA and RNA hybridization probes from plasmids containing a bacteriophage SP6 promoter. Nucleic Acids Res. 12, 7035-7056.

3. Davanloo, P., Rosenberg, A. H., Dunn, J. J., and Studier, F. W. (1984) Cloning and expression of the gene for bacteriophage T7 RNA polymerase. Proc. Natl. Acad. Sci. USA 81, 2035-2039.

4. Krieg, P. A. and Melton, D. A. (1987) In vitro RNA synthesis with SP6 RNA polymerase. Methods Enzymol. 155, 397-415.

5. Yisraeli, J. K. and Melton, D. A. (1989) Synthesis of long, capped transcripts in vitro by SP6 and T7 RNA polymerases. Methods Enzymol. 180, 42-50.

6. Milligan, J. F. and Uhlenbeck, O. C. (1989) Synthesis of small RNAs using T7 RNA polymerase. Methods Enzymol. 180, 51-62. 
7. Breaker, R. B., Banerji, A., and Joyce, G. F. (1994) Continuous in vitro evolution of bacteriophage RNA polymerase promoters. Biochemistry 33, $11,980-11,986$.

8. Milligan, J. F., Groebe, D. R., Witherell, G. W., and Uhlenbeck, O. C. (1987) Oligoribonucleotide synthesis using T7 RNA polymerase and synthetic DNA templates. Nucleic Acids Res. 15, 8783-8798.

9. Roitsch, T. and Lehle, L. (1989) Requirements for efficient in vitro transcription and translation: a study using yeast invertase as a probe. Biochim. Biophys. Acta 1009, 19-26.

10. Schenbon, E. T. and Mierendorf, R. C. (1985) A novel transcription property of SP6 and T7 RNA polymerases: dependence on template structure. Nucleic Acids Res. 13, 6223-6234.

11. Nam, S. C. and Kang, C. (1988) Transcription initiation site selection and abortive initiation cycling of phage SP6 RNA polymerase. J. Biol. Chem. 263, $19,123-19,127$.

12. Solazzo, M., Spinelli, L., and Cesareni, G. (1987) SP6 RNA polymerase: sequence requirements downstream from the transcription start site. Focus 10, 11-12.

13. Stump, W. T. and K. B. Hall (1993) SP6 RNA polymerase efficiently synthesizes RNA from short double-stranded DNA templates. Nucleic Acids Res. 21, 5480-5484.

14. Moreau, G. (1991). Ph.D. thesis, University of Geneva. RNA binding properties of the Xenopus LA proteins.

15. Taylor, D. R. and Mathews, M. B. (1993) Transcription by SP6 RNA polymerase exhibits an ATP dependence that is influenced by promoter topology. Nucleic Acids Res. 21, 1927-1933.

16. Sappino, A.-P., Huarte, J., Belin, D., and Vassalli, J.-D. (1989) Plasminogen activators in tisue remodeling and invasion: $\mathrm{mRNA}$ localization in mouse ovaries and implanting embryos. J. Cell. Biol. 109, 2471-2479.

17. Jostarndt, K., Puntschart, A., Hoppeler, H., and Billeter, R. (1994) The use of $\left[{ }^{33} \mathrm{P}\right]$-labeled riboprobes for in situ hybridizations: localization of myosin light chain mRNAs in adult human skeletal muscle. Histochem. J. 26, 32-40.

18. Dörries, U., Bartsch, U., Nolte, C., Roth, J., and Schachner, M. (1993) Adaptation of a non-radioactive in situ hybridization method to electron microscopy: detection of tenascin mRNA in mouse cerebellum with digoxigenin-labeled probes and gold-labeled antibodies. Histochemistry 99, 251-262.
19. Kriegsmann, J., Keyszer, G., Geiler, T., Gay, R. E., and Gay, S. (1994) A new double labeling technique for combined in situ hybridization and immunohistochemical analysis. Lab. Invest. 71, 911-917.

20. Egger, D., Troxler, M., and Bienz, K. (1994) Light and electron microscopic in situ hybridization: non-radioactive labeling and detection, double hybridization, and combined hybridization-immunocytochemistry. J. Histochem. Cytochem. 42, 815-822.

21. Pokrovskaya, I. D. and Gurevich, V. V. (1994) In vitro transcription: preparative RNA yields in analytical scale reactions. Anal. Biochem. 220, 420-423.

22. Krieg, P. A. (1991) Improved synthesis of full length RNA probe at reduced incubation temperatures. Nucleic Acids Res. 18, 6463.

23. Belin, D., Mudd, E. A., Prentki, P., Yi-Yi, Y., and Krisch, H. M. (1987) Sense and antisense transcription of bacteriophage T4 gene 32. J. Mol. Biol. 194, 231-243.

24. Mead, D. A., Szczesna-Skorupa, E., and Kemper, B. (1986) Single-stranded DNA blue T7 promoter plasmids. Prot. Eng. 1, 67-74.

25. Vassalli, J.-D., Huarte, J., Bosco, D., Sappino, A.-P., Sappino, N., Velardi, A., Wohlwend, A., Erno, H., Monard, D., and Belin, D. (1993) Protease-nexin $I$ as an androgen-dependent secretory product of the murine seminal vesicle. EMBO J.12, 1871-1878.

26. Macdonald, L. E., Durbin, R. K., and McAllister, W. T. (1994) Characterization of two types of termination signals for bacteriophage T7 RNA polymerase. J. Mol. Biol. 238, 145-158.

27. Curran, J., Marq, J.-B., and Kolakofsky, D. (1992) The Sendai virus nonstructural $C$ proteins specifically inhibit viral mRNA synthesis. Virology 189, 647-656.

28. Hod, Y. (1992) A simplified ribonuclease protection assay. Biotechniques 13, 852,853.

29. Lau, E. T., Kong, R. Y. C., and Cheah, K. S. E. (1993) A critical assessment of the RNase protection assay as a means of determining exon sizes. Anal. Biochem. 209, 360-366.

30. Belin, D.,Wohlwend, A., Schleuning, W.-D., Kruithof, E. K. O., and Vassalli, J.-D. (1989) Facultative polypetide translocation allows a single mRNA to encode the secreted and cytosolic forms of plasminogen activators inhibitor 2. EMBO J. 8, 3287-3294.

31. Scott, P. A. E., Smith, K., Bichmel, R., and Harris, A. L. (1977) reliale external control for RNase protection assays. Nucleic Acids Res. 95, 1305,1306. 